\title{
Morphostructural Relationships and Productive Functionality of Sheep Breeds Used for Terminal Crossbreeding in Chile
}

\author{
Relaciones Morfoestructurales y Funcionalidad Productiva \\ de Razas Ovinas Usadas para Cruzamiento Terminal en Chile
}

\author{
R. de la Barra*; M. E. Martínez** \& A. Carvajal
}

DE LA BARRA, R.; MARTÍNEZ, M. E. \& CARVAJAL, A. Morphostructural relationships and productive functionality of sheep breeds used for terminal crossbreeding in Chile. Int. J. Morphol., 34(3):958-962, 2016.

SUMMARY: The body shape of an animal population determines ranges of biological functionality and productive use. In sheep, meat productivity is closely related with the body size of the animal. Some sheep breeds are used in terminal crossbreeding to give the lamb favorable dimensional characteristics, but it is necessary to go deeper on the study of the relationships between morphostructure and productive aptitude of these breeds, since discrepancies could be due to the environmental effects or the degree of differentiation between the original pool of different breeds and the local populations. The study aimed to evaluate the morphostructural characters in four sheep breeds in Chile and discuss their relationship with the productive functionality of the body architecture. Two hundred and seventy-eight sheep belonging to Texel, Dorset, Coopworth and Suffolk Down breeds were used. Eleven body measurements (heart girth circumference, rump width, rump length, width of the cranium, length of the cranium, dorsal-sternal diameter, bicostal diameter, longitudinal diameter, cannon bone circumference, height at rump and height at withers) were taken. Nine zoometric indices (body index, cephalic index, thorax index, thorax depth index, pelvic index, longitudinal pelvic index, transverse pelvic index), metacarpal thorax index and metacarpal costal index) were composed from the individual measurements. The most important morphostructural relationships that contribute to explain the variability of the format of the four breeds of sheep studied were expressed by the metacarpalthoracic index, the metacarpal-costal index, the thorax index and the bicostal index. Moreover, the breeds showed a high dispersion; the zoometric indices only partially explained the variability of the body format, expressing high format heterogeneity in influential variables as the metacarpal-thoracic index, the metacarpal-costal index and the body index. This could be because these racial populations are subjected to processes of differentiation within each breed.

KEY WORDS: Zoometry; Crossbreeding; Sheep.

\section{INTRODUCTION}

Efficiency in the production and marketing of sheep meat depends of two main factors. Specific dimensions of the carcasses produced and processed and on farmers and animal breeders agreement with this need (Kirton et al., 1995). In this sense, the body shape of an animal population determines ranges of biological functionality and productive use (Bravo \& Sepulveda, 2010; Toro et al., 2010). Body measurements, which give significant information on morphological structure and development ability of animals, are the most influential factors on determining animals that are appropriate for the desired efficiency, and on determination of whether the establishment is in development or recession. Especially, to provide increases in meat productivity, which is closely related with the body size of the animal. It is aimed to bring up animals that are portly and have a long, wide and deep body (Abdel-Moneim, 2009; Kilic \& Özbeyaz, 2011). Moreover, body measurements can be considered as morphologic characters that can provide comprehensive information to complete investigations on the performance of sheep breeds (Yakubu, 2010; Cardoso et al., 2013; Parés-Casanova, 2013). Positive genetic and phenotypic correlations indicate that improvement in body measurements both at the genetic and phenotypic levels is expected through selection on body weight and vice versa (Abbasi \& Ghafouri-Kesbi, 2011; Thiagarajan \& Jayashankar, 2012). Based on these criteria, some breeds are used in terminal crossbreeding to give the lamb favorable dimensional characteristics (Bianchi et al., 2006; Cardoso et al.).

\footnotetext{
* Instituto de Investigaciones Agropecuarias (INIA), Centro Regional Remehue, Osorno, Chile.

** Instituto de Investigaciones Agropecuarias (INIA), Centro Experimental Butalcura, Chiloé, Chile.
} 
Animal morphostructure is a productive tool that allows projecting the distinctive attributes of an animal population on the results of a farm using phenotypic criteria (Sierra Alfranca, 2001). Therefore, the phenotypic characterization of animal breeds is important, since their use (directly or in crossbreeding) is crucial in the production and the efficiency of use (Kirton et al.; Janssens \& Vandepitte, 2004; Bianchi et al.; Cardoso et al.). However, it is necessary to go deeper on the study of the relationships between morphostructure and productive aptitude, since discrepancies could be due to the environmental effects or the degree of differentiation between the original pool of different breeds and the local populations (de la Barra et al., 2015).

This study aimed to evaluate the morphostructural characters in four sheep breeds in Chile and discuss their relationship with the productive functionality of the body architecture.

\section{MATERIAL AND METHOD}

The study was conducted between 2011 and 2012 . Two hundred and seventy-eight sheep belonging to four breeds were studied: 56 Texel (TE), 65 Dorset (DO), 46 Coopworth (COO) and 111 Suffolk Down (SU). Eleven body measurements were taken: heart girth circumference (Thp), rump width (Wr), rump length (Rl), width of the cranium $(\mathrm{CraW})$, length of the cranium (CraL), dorsal- sternal diameter (Dd), bicostal diameter (Bd), longitudinal diameter $(\mathrm{Ld})$, cannon bone circumference $(\mathrm{CBC})$, height at rump $(\mathrm{Rh})$ and height at withers (Wh).

Nine zoometric indices were composed from the individual measurements: Body index (BI), Cephalic index (CI), Thorax index (IT), thorax depth index (TDI), pelvic index (PI) longitudinal pelvic index (LPI), transverse pelvic index (TPI), metacarpal thorax index (MTI) and metacarpal costal index (MCI). Data were analyzed by Fisher LSD test and principal component analysis using for the XLSTAT Pro statistical package.

\section{RESULTS AND DISCUSSION}

Animal morphostructure is defined by body dimensions and the relationships between them. These relationships determine the productive functionality and suitability of the animal in the meat, milk or dual purpose performance. The zoometric indices represent these relations and show the biological and productive functionality of a given animal biotype (Parés-Casanova, 2009; Bravo \& Sepúlveda).

Figure 1 shows the result of principal component analysis of the zoometric indexes in the four breeds evaluated. Figure 1a it shows that the main components cumulatively explained $52.89 \%$ of the variability (F1 30.41 y F2 22.48), indicating that the analyzed breeds had a high

\section{a) Cases (ejes F1 y F2: 52,89 \%)}
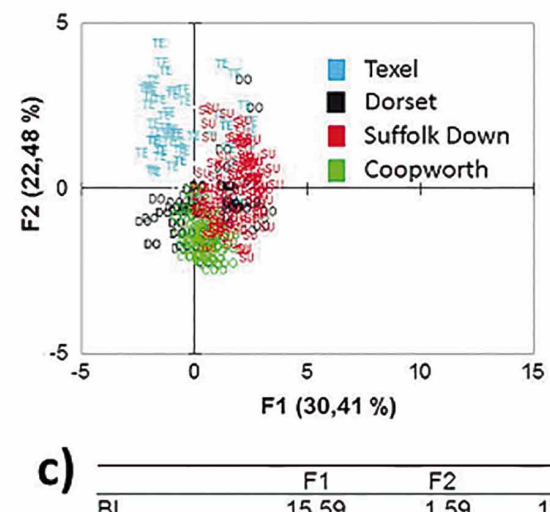

\begin{tabular}{|c|c|c|c|c|c|c|c|}
\hline & F1 & F2 & F3 & $\mathrm{F} 4$ & F5 & F6 & $\mathrm{F} 7$ \\
\hline$\overline{B I}$ & 15,59 & 1,59 & 11,68 & 25,11 & 0,41 & 0,81 & 11,74 \\
\hline $\mathrm{Cl}$ & 0,0 & 42,21 & 4,69 & 0,58 & 3,84 & 4,30 & 1,87 \\
\hline IT & 15,91 & 0,86 & 0,00 & 17,24 & 29,94 & 5,07 & 27,60 \\
\hline TOI & 6,91 & 1,54 & 4,35 & 11,39 & 62,38 & 6,65 & 6,10 \\
\hline $\mathrm{PI}$ & 2,98 & 42,65 & 1,35 & 0,27 & 1,05 & 0,34 & 0,90 \\
\hline LPI & 7,62 & 0,01 & 38,93 & 3,47 & 0,06 & 45,44 & 4,45 \\
\hline TPI & 6,21 & 7,20 & 26,46 & 11,38 & 1,13 & 32,60 & 9,82 \\
\hline MTI & 22,58 & 3,26 & 11,94 & 7,99 & 0,62 & 1,32 & 4,58 \\
\hline $\mathrm{MCl}$ & 22,16 & 0.63 & 0,57 & 22,52 & 0.53 & 3,43 & 32,91 \\
\hline
\end{tabular}

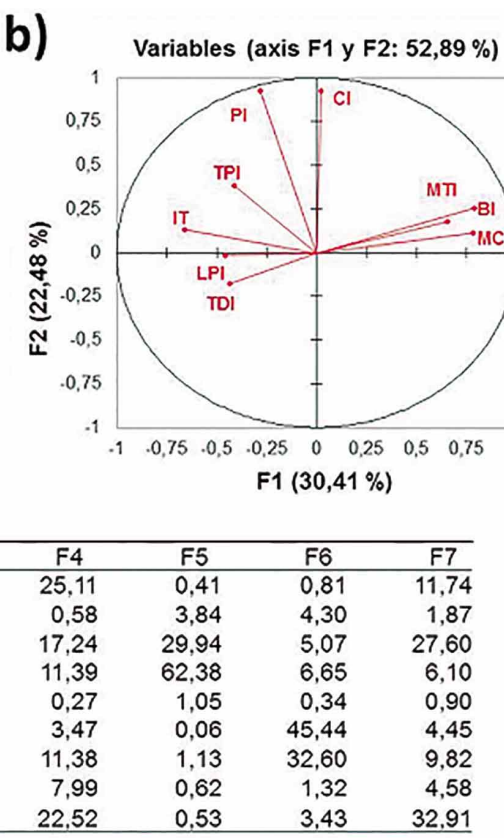

Fig. 1. Principal component analysis; a) Distribution of individuals of each breed in the plane; b) Variability of zoometric indices in the plane; c) Contribution of zoometric indices to the variability of each principal component. 
dispersion, and the zoometric indices explain the body format variability only partially. This may be because these populations have racial differentiation processes within each breed due to hybridity, divergent patterns of selection, incomplete absorption or inbreeding (Sierra Alfranca; de la Barra et al., 2010, 2013; Latorre et al., 2011). It can also be seen that Texel, Suffolk Down and Coopworth are separately grouped; however, Dorset does not conform a clear group.

Three groups of indexes appear in Figure 1b. One group clustering MTI, BI and MCI; the second group, in opposition to the former, composed by LTI, IT, LPI and TDI. Furthermore, PI and CI generated a third group, not related to the other two.

Figure 1c shows the variables that contribute most to explain the whole variability. MTI (22.58), MCI (22.16), IT (15.91) and B1 (15.59) are the indices that contribute most to explain the body functionality of these sheep breeds. This is consistent with the works that point to such measures as definers of the meat or dual-purpose aptitude of an animal (Parés-Casanova, 2009; Bravo \& Sepúlveda; Carneiro et al., 2010; Abbasi \& Ghafouri-Kesbi; Mujica et al., 2012).

The correlations between zoometric indices are showed in Table I. BI had a high positive correlation (0.906) with MTI. IT shown a high negative correlation (-0.720) with $\mathrm{MCI}$. These indices are relevant and defining on the F1 component (Fig. 1). These variables associated with meat ability and their functional relationships define the body pattern of pure or crossbred lambs (Parés-Casanova, 2009; Bravo \& Sepúlveda). Although there are other variables positively correlated as PI with CI or TPI with LPI, they are of little influence on the general format of all breeds.

Table II shows the morphometric measures of the analyzed breeds. Fort BI, two different groups were observed: Dorset (75.20) and Suffolk Down (75.92) breeds showed the highest BI values, while Texel (68.08) and
Coopworth (69.16) were the lowest. All breeds were confined to the brevilineal Baron biotypes systematic (Parés-Casanova, 2009), that may be related to a higher aptitude for meat production (Salako, 2006; Parés-Casanova, 2009).

A high IT reflects a circular shaped section of the chest; which is associated with a meat body functionality. On the other hand, an elliptical section is associated to a dual purpose (Parés-Casanova, 2009). The breed with the highest IT and therefore with greater meat functionality was TE. The lowest IT was found in SU. DO and COO were intermediate and did not differ; nevertheless, the IT values found in the four breeds studied put them away from dual purpose (Nudda et al., 2002; Latorre et al.; de la Barra et al., 2011; Mujica et al.), and give them a clear meat aptitude (Janssens \& Vandepitte).

MTI establishes a relationship between the mass of the animal and the limbs holding this mass (Bravo \& Sepúlveda). The analyzed breeds showed MTI values that lie within a trend towards meat production, with DO and SU values significantly higher than those exhibited by TE and COO. These two breeds also showed meat ability, but with a less compact format.

For MCI, several groups with significant differences were also formed. The biggest MCI was found in SU, followed by DO and the group of TE and COO, who had the lower values, without significant differences.

According to the MCI values obtained, the four breeds had a high aptitude for meat production (Janssens \& Vandepitte; Bravo \& Sepulveda), which is reinforced with the ranges of the values achieved by TDI, LPI and TPI (Bravo \& Sepulveda; Carneiro et al.). Very high coefficients of variation were observed in TE, DO and SU, revealing problems in the format homogeneity for these breeds, possibly due to hybridity, divergent pattern selection, incomplete absorption or inbreeding (Sierra Alfranca; de la Barra et al., 2010, 2013; Latorre et al.).

Table I. Pearson Correlation matrix of zoometric indices.

\begin{tabular}{lccccccccc}
\hline Variables & BI & CI & IT & TDI & PI & LPI & TPI & MTI & MCI \\
\hline BI & 1 & 0.103 & -0.147 & -0.051 & -0.115 & -0.088 & -0.140 & 0.906 & 0.219 \\
CI & 0.103 & 1 & 0.061 & -0.087 & 0.887 & -0.206 & 0.083 & 0.147 & 0.062 \\
IT & -0.147 & 0.061 & 1 & 0.116 & 0.223 & 0.177 & 0.193 & -0.273 & -0.722 \\
TDI & -0.051 & -0.087 & 0.116 & 1 & -0.039 & 0.260 & 0.087 & -0.187 & -0.453 \\
PI & -0.115 & 0.887 & 0.223 & -0.039 & 1 & 0.024 & 0.383 & -0.076 & -0.104 \\
LPI & -0.088 & -0.206 & 0.177 & 0.260 & 0.024 & 1 & 0.632 & -0.113 & -0.187 \\
TPI & -0.140 & 0.083 & 0.193 & 0.087 & 0.383 & 0.632 & 1 & -0.063 & -0.017 \\
MTI & 0.906 & 0.147 & -0.273 & -0.187 & -0.076 & -0.113 & -0.063 & 1 & 0.526 \\
MCI & 0.219 & 0.062 & -0.722 & -0.453 & -0.104 & -0.187 & -0.017 & 0.526 & 1 \\
\hline B & & & & & & & & &
\end{tabular}

Bolded numbers indicate statistical significance ( $\mathrm{p} \leq 0.05$ ) 
Table II. Mean and standard deviation of morphostructural measurements in four sheep breeds of Chile.

\begin{tabular}{|c|c|c|c|c|c|c|c|c|}
\hline \multirow{2}{*}{ Index } & \multicolumn{2}{|l|}{ TE } & \multicolumn{2}{|l|}{ DO } & \multicolumn{2}{|l|}{$\mathrm{COO}$} & \multicolumn{2}{|l|}{ SU } \\
\hline & Mean \pm SD & v.c. & Mean \pm SD & v.c. & Mean \pm SD & v.c. & Mean \pm SD & v.c. \\
\hline BI & $68.08 \pm 5.02 b$ & 7.37 & $75.20 \pm 7.12 \mathrm{a}$ & 9.47 & $69.16 \pm 3.89 b$ & 5.63 & $72.85 \pm 5.24 a$ & 7.19 \\
\hline CI & $164.55 \pm 24.20 \mathrm{a}$ & 14.71 & $96.41 \pm 16.51 \mathrm{c}$ & 17.13 & $82.27 \pm 7.30 \mathrm{~d}$ & 8.88 & $130.52 \pm 25.53 b$ & 19.56 \\
\hline IT & $91.80 \pm 7.67 \mathrm{a}$ & 8.36 & $85.90 \pm 9.47 b$ & 11.02 & $84.71 \pm 7.10 b$ & 8.38 & $76.94 \pm 7.51 \mathrm{c}$ & 9.77 \\
\hline TDI & $51.97 \pm 4.18 b$ & 8.05 & $51.07 \pm 2.89 \mathrm{~b} . \mathrm{c}$ & 5.66 & $53.38 \pm 2.77 \mathrm{a}$ & 5.14 & $50.51 \pm 3.21 \mathrm{c}$ & 6.35 \\
\hline PI & $347.53 \pm 60.94 \mathrm{a}$ & 17.54 & $201.29 \pm 32.60 \mathrm{c}$ & 16.20 & $165.50 \pm 15.85 \mathrm{~d}$ & 9.58 & $235.31 \pm 42.02 b$ & 17.86 \\
\hline LPI & $29.10 \pm 4.28 b$ & 14.71 & $29.42 \pm 2.73 b$ & 9.27 & $31.46 \pm 2.91 \mathrm{a}$ & 9.24 & $26.17 \pm 3.69 \mathrm{c}$ & 14.11 \\
\hline TPI & $29.96 \pm 3.13 \mathrm{a}$ & 10.46 & $29.57 \pm 2.70 \mathrm{a}$ & 9.14 & $28.55 \pm 2.03 b$ & 7.11 & $26.16 \pm 3.46 \mathrm{c}$ & 13.22 \\
\hline MTI & $9.89 \pm 1.85 b$ & 18.71 & $11.16 \pm 2.40 \mathrm{a}$ & 21.54 & $9.68 \pm 0.77 b$ & 8.00 & $10.86 \pm 1.75 \mathrm{a}$ & 16.10 \\
\hline MCI & $35.41 \pm 7.68 \mathrm{c}$ & 21.68 & $41.06 \pm 10.30 \mathrm{~b}$ & 25.07 & $37.13 \pm 2.94 \mathrm{c}$ & 7.92 & $45.69 \pm 10.68 a$ & 23.38 \\
\hline
\end{tabular}

TE: texel; DO: Dorset; COO: Coopworth; SU: Suffolk Down; BI: Body index; CI: Cephalic index; IT: Thorax index; TDI: thorax depth index; PI: Pelvic index; LPI: Longitudinal pelvic Index; TPI: transverse pelvic index; MTI: metacarpal thorax index; MCI: Metacarpal costal index. a, b, c: Within a column, different letters indicate statistically significant differences ( $\mathrm{p} \leq 0.05$ ).

$\mathrm{CI}$ is more useful in breed diagnosis than in the definition of productive capabilities, since its variation is not influenced by environmental factors or handling (Sierra Alfranca; Parés-Casanova, 2009). In this study, we determined that CI statistically separated every breed from the others. COO presented the lowest value, with a head close to a square format, and at the higher belonged to TE, with an elongated rectangular head format. DO and SU were intermediate. The striking variation coefficients of TE, DO and SU denoted a high variability in the racial constitution of these populations; the marked differences could be due to problems of hybridity, divergent patterns selection, incomplete absorption or inbreeding, as mentioned above (Sierra Alfranca; de la Barra et al., 2010, 2013; Latorre et al.).

\section{CONCLUSIONS}

The most important morphostructural relationships that contribute to explain the variability of the format of the four breeds of sheep studied were expressed by the metacarpal-thoracic index, the metacarpal-costal index, the thorax index and the bicostal index. Moreover, the breeds showed a high dispersion; the zoometric indices only partially explained the variability of the body format, expressing a high format heterogeneity in influential variables as the metacarpal-thoracic index, the metacarpal-costal index and the body index. This could be because these racial populations are subjected to processes of differentiation within each breed.

\section{ACKNOWLEDGMENTS}

To Consorcio Ovino S.A. and to sheep breeders, for their active collaboration.
DE LA BARRA, R.; MARTÍNEZ, M. E. \& CARVAJAL, A. Relaciones morfoestructurales y funcionalidad productiva de razas ovinas usadas para cruzamiento terminal en Chile. Int. J. Morphol., 34(3):958-962, 2016.

RESUMEN: La forma del cuerpo de una población animal determina rangos de funcionalidad biológica y su uso productivo. En las ovejas, la productividad de la carne está muy relacionada con el tamaño del cuerpo del animal. Algunas razas de ovejas se utilizan en cruzamientos terminales para dar al cordero características dimensionales favorables, pero es necesario profundizar en el estudio de las relaciones entre morfoestructura y aptitud productiva de estas razas, ya que las discrepancias podrían deberse a los efectos del medio ambiente o al grado de la diferenciación entre la piscina original de diferentes razas y las poblaciones locales. Este trabajo tuvo como objetivo evaluar los caracteres morfoestructurales en cuatro razas de ovinos en Chile y la relación de la funcionalidad productiva con la arquitectura del cuerpo. Se utilizaron 278 ovejas, raza Suffolk Down, pertenecientes a Texel, Dorset, Coopworth. Se tomaron 11 mediciones en el cuerpo (circunferencia del corazón, ancho del lomo, rabadilla, ancho del cráneo, longitud del cráneo, diámetro esternaldorsal, diámetro bicostal, diámetro longitudinal, circunferencia de hueso de la caña, altura de cadera y altura a la cruz). Nueve índices zoométricos (índice corporal, índice cefálico, índice de tórax, índice de profundidad del tórax, índice de la pelvis, índice pélvico longitudinal, índice transversal de la pelvis, índice metacarpiano del tórax e índice metacarpiano costal) fueron determinados a partir de mediciones individuales. Las relaciones morfoestructurales más importantes que contribuyen a explicar la variabilidad del formato de las cuatro razas de ovejas estudiadas se expresaron por el índice metacarpiano-torácico, el índice metacarpiano-costal, el índice de tórax y el índice bicostal. Por otra parte, las razas mostraron una alta dispersión de los índices zoométricos que explican sólo parcialmente la variabilidad del formato de cuerpo, la alto heterogeneidad de formato en las variables influyentes como el índice metacarpiano-torácica, el índice metacarpiano-costal y el índice del cuerpo. Esto podría ser debido a que estas poblaciones raciales son sometidos a procesos de diferenciación dentro de cada raza.

PALABRAS CLAVE: Zoometría; Cruce; Oveja. 


\section{REFERENCES}

Abbasi, M. \& Ghafouri-Kesbi, F. Genetic (co)variance components for body weight and body measurements in makooei sheep. Asian Australas. J. Anim. Sci., 24(6):739-43, 2011.

Abdel-Moneim, A. Y. Use of live body measurements for prediction of body and carcass cuts weights in three Egyptian breeds of sheep. Egypt. J. Sheep Goat Sci., 4(2):17-32, 2009.

Bianchi, G.; Garibotto, G.; Feed, O.; Bentancur, O. \& Franco, J. Efecto del peso al sacrificio sobre la calidad de la canal y de la carne de corderos Corriedale puros y cruza. Arch. Med. Vet., 38(2):161-5, 2006.

Bravo, S. \& Sepúlveda, N. Zoometric indices in Araucanas creole ewes. Int. J. Morphol., 28(2):489-95, 2010.

Cardoso, M. T. M.; Landim, A. V.; Louvandini, H. \& McManus, C. Performance and carcass quality in three genetic groups of sheep in Brazil. Rev. Bras. Zootec., 42(10):734-42, 2013.

Carneiro, H.; Louvandini, H.; Paiva, S. R.; Macedo, F.; Mernies, B. \& McManus, C. Morphological characterization of sheep breeds in Brazil, Uruguay and Colombia. Small Rum. Res., 94(1-3):58$65,2010$.

de la Barra, R.; Uribe, H.; Latorre, E.; San Primitivo, F. \& Arranz, J. J. Genetic structure and diversity of four Chilean sheep breeds. Chil. J. Agric. Res., 70(4):646-51, 2010.

de la Barra, R.; Carvajal, A.; Uribe, H.; Martínez, M. E.; Gonzalo, C.; San Primitivo, F. \& Arranz, J. J. El ovino criollo Chilote y su potencial productivo. Anim. Genet. Resour., 48:93-9, 2011.

de la Barra, R.; Martínez, M. E.; Calderón, C. \& Latorre, E. Intergenerational morphostructural stability and harmony of Marin Magellan meat merino ewes. Int. J. Morphol., 31(4):1455$8,2013$.

de la Barra, R.; Carvajal, A.; Calderón, C. \& Squella, F. Body architecture of main sheep breeds in Chile. J. Anim. Ethnol., 1:1-9, 2015.

Janssens, S. \& Vandepitte, W. Genetic parameters for body measurements and linear type traits in Belgian Bleu du Maine, Suffolk and Texel sheep. Small Rum. Res., 54(1-2):13-24, 2004.

Kilic, I. \& Özbeyaz, C. Classification of Karayaka and Bafra (Chios $\mathrm{x}$ Karayaka B1) sheep according to body measurements by different clustering methods. Ankara Üniv. Vet. Fak. Derg., 58:203-8, 2011.

Kirton, A. H.; Carter, A. H.; Clarke, J. N.; Sinclair, D. P.; Mercer, G. J. K. \& Duganzich, D. M. A comparison between 15 ram breeds for export lamb production 1. Liveweights, body components, carcass measurements, and composition. N. Z. J. Agric. Res., 38(3):347-60, 1995.
Latorre, E.; Uribe, H.; Martínez, M. E.; Calderón, C. \& de la Barra, R. Morphology differentiation and structural functionality of ewes due to incomplete crossbreeding. Int. J. Morphol., 29(3):954-9, 2011.

Mujica, F.; Mella, J.; de la Barra, R. \& Blanco, A. Caracterización fenotípica de la raza ovina criolla Chilota y dos razas ovinas predominantes en el sur de Chile. Actas Iberoam. Conserv. Anim., 2:67-70, 2012.

Nudda, A.; Bencini, R.; Mijatovic, S. \& Pulina, G. The yield and composition of milk in Sarda, Awassi, and Merino sheep milked unilaterally at different frequencies. J. Dairy Sci., 85(11):287984, 2002.

Parés-Casanova, P. Zoometría. Madrid, Valoración Morfológica de los animales domésticos. Ministerio de medio ambiente y medio rural y marino, Gobierno de España, 2009.

Parés-Casanova, P. M. Morphometric dimensions allow differentiation of lamb carcasses for some breeds. Egypt. J. Sheep Goat Sci., 8(1):167-70, 2013.

Salako, A. E. Application of morphological indexes in the assessment of type and function in sheep. Int. J. Morphol., 24(1):13-8, 2006.

Sierra Alfranca, I. El concepto de raza: evolución y realidad. Arch. Zootec., 50(192):547-64, 2001.

Thiagarajan, R. \& Jayashankar, M. R. Effect of genetic and nongenetic factors on staple length in indigenous and crossbreed sheep. Res. J. Anim.Sci., 6(1):1-3, 2012.

Toro, I. M. V.; Manríquez, S. G. \& Suazo, G. I. Geometric morphometry and the biologic shapes study: From the descriptive morphology to the quantitative morphology. Int. J. Morphol., 28(4):977-90, 2010.

Yakubu, A. Path coefficient and path analysis of body weight and biometric traits in Yankasa lambs. Slovak J. Anim. Sci., 43(1):1725, 2010.

Correspondence to:

María Eugenia Martínez P.

Investigadora Alimentación de Rumiantes

INIA

O'Higgins 415-A of. 14

Castro, Chiloé

CHILE

Email: eugemartinez.inia@gmail.com

Received: 17-11-2015

Accepted: 07-07-2016 